\title{
Granular phagostimulant nucleopolyhedrovirus formulations for control of Spodoptera frugiperda in maize
}

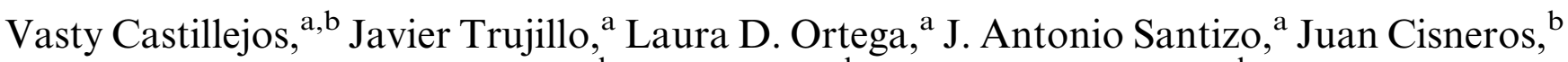 \\ Dora I. Penagos, ${ }^{\mathrm{b}}$ Javier Valle, ${ }^{\mathrm{b}}$ and Trevor Williams ${ }^{\mathrm{b}, *}$ \\ a Instituto de Fitosanidad, Colegio de Posgraduados, Montecillo, Texcoco 56230, Estado de México, Mexico \\ ${ }^{\mathrm{b}}$ ECOSUR, Apdo. Postal 36, Carr. Antiguo Aeropuerto KM2.5, Tapachula, Chiapas 30700, Mexico
}

Received 29 November 2001; accepted 26 January 2002

\begin{abstract}
The efficacy of bioinsecticides that act by ingestion can be improved by the use of phagostimulant formulations that increase the consumption of the pathogen. A granule recipe comprising of pregelatinized flour, starch, ground maize cob, maize oil, and water was identified that was highly palatable to Spodoptera frugiperda larvae. To compare the performance of a multiple nucleopolyhedrovirus (SfMNPV) in aqueous spray and phagostimulant granules, multiple linear regression procedures were employed to analyze the results of seven independent field trials involving spray applications and eight independent field trials involving application of phagostimulant granules for control of $S$. frugiperda in maize. Prevalence of infection was positively correlated with the quantity of inoculum applied but negatively correlated with the interval between application and sampling of larvae for both granular and spray formulations. Virus-induced mortality was greater when inoculum was applied in granular than in spray formulation. A field experiment involving the application of $1.5 \times 10^{12}$ occlusion bodies $(\mathrm{OBs}) / \mathrm{ha}$ in quantities of 6,18 , and $32 \mathrm{~kg}$ granules/ha indicated that the quantity of granules applied did not significantly affect viral mortality at any timepoint. Persistence of activity of viral inoculum applied in spray or granular formulations was significantly greater when applied in the granular formulation, with approximately $23 \%$ of the original activity remaining at 8 days postapplication compared to $<1 \%$ in the spray-treated plants. We conclude that the efficacy of SfMNPV was improved by formulation; the granular formulation caused a higher prevalence of infection in $S$. frugiperda larvae and persisted longer on crop foliage compared to an aqueous spray application. The cost of the formulation ingredients alone was approximately US\$0.50/kg. When combined with the virus, the cost of the basic bioinsecticide components would be about US\$17/ha, although this estimate does not include additional costs involved in the commercialization of a potential bioinsecticide product. (C) 2002 Elsevier Science (USA). All rights reserved.
\end{abstract}

Keywords: Maize flour granules; Baculovirus; Biopesticide formulation; Efficacy; Persistence

\section{Introduction}

Insect baculoviruses have an established history of use as biological insecticides due to their high virulence and high specificity and the fact that can be applied to crops using conventional equipment designed for chemical insecticides (Hunter-Fujita et al., 1998). However, two key factors often limit their efficacy as bioinsecticides in the field. First, the need for precise delivery of the inoculum to the feeding site of the target pest and second, the rapid inactivation of viral occlusion

\footnotetext{
${ }^{*}$ Corresponding author. Fax: +52-962-628-1015.

E-mail address: trevw@tap-ecosur.edu.mx (T. Williams).
}

bodies (OBs) by solar UV radiation (Jones et al., 1997). These limiting factors may be of even greater importance when attempting to control semi-cryptic pests such as codling moth Cydia pomonella (L.), cutworms Agrotis spp., or fall armyworm larvae Spodoptera frugiperda (J.E. Smith).

Formulation can play an important role in stabilizing the pathogen during storage and in facilitating the handling and application of bioinsecticidal products by farmers used to dealing with chemicals (Jones and Burges, 1998). Moreover, certain formulations can improve the degree of pest control through the use of baits or feeding stimulants that enhance the pest's consumption of viral inoculum while simultaneously protecting 
the virus from UV degradation (Bartelt et al., 1990; McGuire et al., 1996).

Recent studies have indicated that phagostimulant maize flour-based formulations of Bacillus thuringiensis Berliner and nucelopolyhedrovirus resulted in improved control of various species of noctuid pests (MoralesRamos et al., 1998, Tamez-Guerra et al., 1998). Moreover, the maize flour formulation offered increased protection from UV radiation and improved the rainfastness of the inoculum during simulated rainfall (Tamez-Guerra et al., 2000a,b).

The fall armyworm is a major pest of maize and sorghum in America. Crop infestation exceeding 55\% can result in grain yield losses of $15-73 \%$ in Central America (Hruska and Gould, 1997). The feeding damage caused by $S$. frugiperda larvae is highly apparent and farmers usually apply organophosphate insecticides to control this pest several times during the growing season. Inadequate protection during handling and application of these chemicals has resulted in a disturbingly high prevalence of chronic farmer intoxication by pesticides in Mexico and Central America (Hunt et al., 1999; McConnell and Hruska, 1993; Tinoco and Halperin, 1998).

This has motivated a program focused on the development of a nucleopolyhedrovirus-based biological insecticide for safe and effective control of $S$. frugiperda in maize. Spray application of $1.5 \times 10^{12} \mathrm{OBs} / \mathrm{ha}$ typically results in $40 \%$ infection of $S$. frugiperda larvae collected at 2 days postapplication and reared in the laboratory (Martínez et al., 2000), with natural parasitism contributing an additional $20 \%$ to pest mortality. Our present study, therefore, is designed to evaluate the feasibility of formulating the multiple nucleopolyhedrovirus of $S$. frugiperda (SfMNPV) as phagostimulant granules for improved control of this pest in maize.

The objectives of the study were fourfold. First, to determine the palatability-cost relationship for a number of different granule recipes, taking into account the physical characteristics of the formulation. Second, to compare the degree of pest control achieved by means of a phagostimulant formulation with that of an aqueous spray. Third, to determine the relationship between the quantity of granules applied and the mortality of the pest. Finally to compare the persistence of inocula applied in spray or granule formulations to maize plants in the field.

\section{Materials and methods}

\subsection{Insects and virus}

A colony of $S$. frugiperda that originated with larvae collected from maize plants within a $30-\mathrm{km}$ radius of Tapachula, Chiapas, Mexico was maintained at 24 $27^{\circ} \mathrm{C} 12 \mathrm{~h}: 12 \mathrm{~h} \mathrm{~L}: \mathrm{D}, 75-90 \%$ R.H. on a semi-synthetic diet based on maize flour, ground soya, and brewer's yeast (adapted from Mihm, 1984).

The SfMNPV isolate from Nicaragua was produced by inoculation of fourth-instar $S$. frugiperda using the contaminated diet technique described elsewhere (Cisneros et al., 2002b). The SfMNPV isolate had previously been characterized by Escribano et al. (1999). Infected larvae were individually maintained at $25 \pm 1{ }^{\circ} \mathrm{C}$ in $25 \mathrm{ml}$ plastic cups containing semi-synthetic diet. Viruskilled larvae were triturated in $0.1 \%(\mathrm{w} / \mathrm{v})$ sodium dodecylsulfate (SDS) and centrifuged at $90 \mathrm{~g}$ for $5 \mathrm{~min}$, and the supernatant was centrifuged at $3000 \mathrm{~g}$ for $10 \mathrm{~min}$. Pelleted OBs were resuspended in sterile distilled water, counted using a bacterial counting chamber, and stored at $4{ }^{\circ} \mathrm{C}$ for up to 2 weeks prior to use.

\subsection{Palatability of phagostimulant mixtures}

A selection of granule recipes was tested for their palatability to $S$. frugiperda larvae with the aim of identifying a low-cost recipe with good phagostimulant properties. The handling characteristics, i.e., physical form of the granules, were also assessed. Granules were prepared as described previously (Cisneros et al., 2002a). Briefly, various quantities of nixtamalized maize flour, starch, Neosyl Ts (synthetic silica, Crosfield Chemicals, Warrington, UK), and maize oil were thoroughly mixed and water was added to make a stiff dough. A virus suspension was added to the water prior to mixing to give a final concentration of $5 \times 10^{10} \mathrm{OBs} / \mathrm{kg}$ of granules. The dough was left at $25 \pm 1^{\circ} \mathrm{C}$ for a period of $1 \mathrm{~h}$ and then passed through a wire sieve with a mesh aperture of $1.2 \mathrm{~mm}$. During this process, the dough crumbled into irregular granules approximately $1 \mathrm{~mm}$ wide and $0.5-3 \mathrm{~mm}$ in length. These granules were placed next to a fan ventilator and allowed to air dry overnight prior to use.

Each granule recipe was compared to the standard laboratory semi-synthetic diet contaminated with $5 \times 10^{10} \mathrm{OBs} /$ liter by thorough mixing prior to solidification of the diet. Fifty portions of $0.5 \mathrm{~g}$ of each type of granule or contaminated diet were placed in $25 \mathrm{ml}$ plastic cups and dampened using a hand-held sprayer containing distilled water. Previous tests indicated that survival of $S$. frugiperda larvae was improved when the granules were damp. A single second-instar $S$. frugiperda was placed in each cup, which was then sealed and incubated at $26 \pm 1{ }^{\circ} \mathrm{C}$. After $24 \mathrm{~h}$, each larva was individually transferred to a separate plastic cup containing uncontaminated semi-synthetic diet. Larvae were checked for signs of virus infection every $12 \mathrm{~h}$ until death or pupation. Control larvae were treated identically, but were offered granules or diet that did not contain virus. The experiment was performed three times. 
Mortality data were analyzed in GLIM (Numerical Algorithms Group, 1993) with binomial errors specified. Small degrees of overdispersion were taken into account by scaling the error distribution and calculating the significance of changes in model deviance in terms of $F$ statistics (Crawley, 1993). Mean time to death data were subjected to analysis in GLIM following $\log _{\mathrm{e}}$ transformation. Individuals that did not succumb to virus infection were excluded from the analysis (Farrar and Ridgway, 1998). Treatment differences were calculated by $t$ test comparison of treatment means (Crawley, 1993). The distribution of residuals and fitted values was determined using the model checking macros present in the GLIM program.

\subsection{Comparison of spray and phagostimulant formula- tions}

To compare the performance of SfMPNV in aqueous spray and phagostimulant granules, we gathered the results of seven independent field trials involving spray applications and eight independent field trials involving application of phagostimulant granules. The results of three of the spray trials (Martínez et al., 2000; Williams et al., 1999) and one of the granule trials (Cisneros et al., 2002b) have been published previously, whereas the remainder represent unpublished studies. All the trials were performed in the southern States of Chiapas and Oaxaca, Mexico using a number of locally grown maize varieties in the mid- to late-whorl stages. Additional treatments involving different virus formulations or chemical control measures were often included in the various field trials, but the results from plots that received such treatments were not included in the present analysis.

In all cases, data were collected in a similar manner. Experimental blocks of maize were planted in $5 \times 5 \mathrm{~m}$, $5 \times 6 \mathrm{~m}$, or $8 \times 8 \mathrm{~m}$ plots and treated at $20-45$ days after planting with an aqueous suspension of the Nicaraguan SfMNPV isolate. At various intervals (1-10 days) of postspraying, 10-20 plants were sampled from each plot and $S$. frugiperda larvae were collected and individually reared on semi-synthetic diet until death or pupation. Virus infection was diagnosed by liquefaction of the insect's body and confirmed by examination of Giemsastained larval smears for the presence of viral OBs. The emergence of parasitoids was also recorded in all except two trials involving the application of granules.

Between one and three concentrations of virus were applied in each trial with a range of $1 \times 10^{11}$ $1.5 \times 10^{12} \mathrm{OBs} / \mathrm{ha}$ either as an aqueous suspension containing a commercial wetter-sticker $(0.02-0.2 \%$ AgralPlus, Zeneca, Mexico) or as maize flour-based granules. The granules were prepared using recipe $\mathrm{A}$ and recipe $\mathrm{E}$ as these recipes had similar palatability in the feeding tests described above (Table 2). Control plots were treated with wetter-sticker solution or blank granules. For all trials 4-10 replicate plots received each treatment. Virus suspension was applied in a volume of between 300 and 811 liters water/ha using a manual knapsack sprayer with a cone nozzle or between 6 and $32 \mathrm{~kg} / \mathrm{ha}$ of maize flour granules. The spray was directed into the leaf whorl by briefly holding the nozzle 10 $15 \mathrm{~cm}$ above the whorl, as described previously (Williams et al., 1999). Granules were sprinkled into the whorl of each plant using a calibrated plastic teaspoon (Williams et al., 1999). The sample size was similar for trials involving both types of formulation (means $\pm \mathrm{SE}$ : $104 \pm 7.6$ larvae/treatment/sample point for trials involving the spray formulation, $138 \pm 8.9$ larvae/treatment/sample point for trials involving the granular formulation).

The percentage prevalence of virus infection and parasitoid emergence was subjected to multiple regression analysis against virus application rate $(\log \mathrm{OBs} / \mathrm{ha})$ and the interval between application and sampling of larvae (SAS Institute, 1992). Percentage infection and parasitism data were normally distributed and did not require transformation prior to analysis. The significance of correlation coefficients was determined by dividing the coefficient by its standard error and comparing the value obtained with a $t$ distribution (Sokal and Rohlf, 1981). The number of larvae collected in each sample was initially included as an explanatory variable but was later removed when found to be insignificant.

\subsection{Application rate for phagostimulant granules}

In June 2001, a field of maize plants (PNS hybrid H134) of 1.5 ha was selected close to the village of Mazatán $\left(14^{\circ} 52^{\prime} \mathrm{N}, 92^{\circ} 27^{\prime} \mathrm{W}\right), 20 \mathrm{~km}$ west of the town of Tapachula, Chiapas, Mexico. The climate in this region is hot $\left(35^{\circ} \mathrm{C}\right.$ day, $23^{\circ} \mathrm{C}$ night $)$ and humid $(85-95 \%$ R.H. $)$ with rainfall common in the late afternoon (approximately $300 \mathrm{~mm} /$ month from May to November). The experimental site was approximately $30 \mathrm{~m}$ above sea level. The maize was planted at a density of approximately 40,000 plants/ha. Plants were in the mid-whorl stage, approximately $50 \mathrm{~cm}$ high and had not been subjected to any prior insecticide treatments.

Plants were divided into experimental blocks of $5 \times 5 \mathrm{~m}$ with a barrier of $5 \mathrm{~m}$ of maize plants between blocks. Plants were manually infested each with three second-instar $S$. frugiperda from the laboratory culture. The following day, each of the blocks was randomly assigned to one of the following virus treatments: $1.5 \times 10^{12} \mathrm{OBs} / \mathrm{ha}$ in (i) $6 \mathrm{~kg}$ granules, (ii) $18 \mathrm{~kg}$ granules, (iii) $32 \mathrm{~kg}$ granules, or (iv) control consisting of $18 \mathrm{~kg} / \mathrm{ha}$ of granules containing no virus. In all cases, the granules were made from recipe $\mathrm{E}$ (Table 1). These quantities (6$32 \mathrm{~kg} / \mathrm{ha}$ ) represented $0.15,0.45$, and $0.80 \mathrm{~g}$ granules/ 
Table 1

Quantity and cost of ingredients used in each of nine granule recipes tested in this study

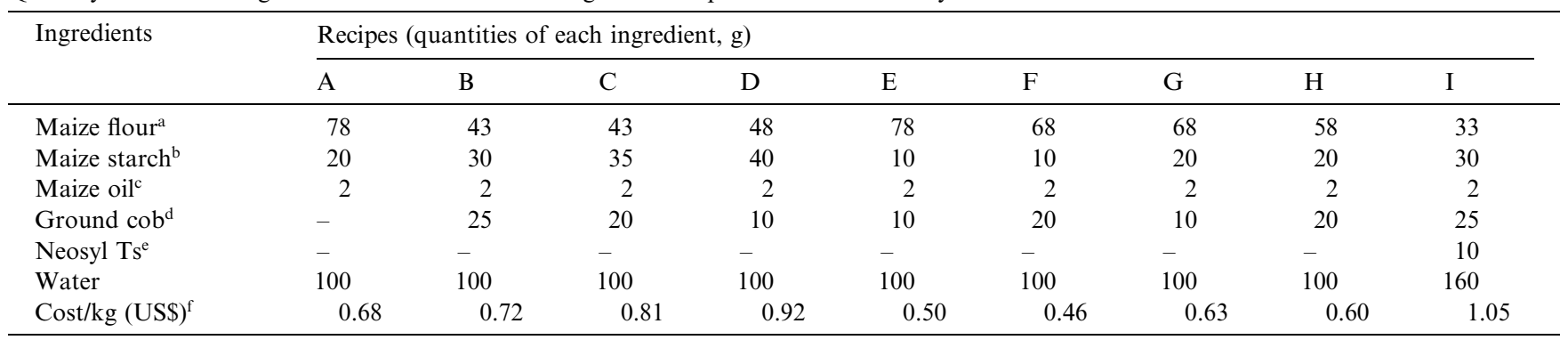

\footnotetext{
${ }^{a}$ Nixtamalized maize flour (Maseca, Molinas Azteca de Chiapas SA de CV, Villaflores, Chiapas, Mexico, batches 178-1 and 199-1). The nixtamalization process involves cooking the maize in an alkaline solution which causes pregelatinization of starch.

${ }^{\mathrm{b}}$ Maizena, Productos de Maíz SA de CV, Lerma, Edo. Méx., Mexico.

${ }^{\mathrm{c}}$ Mazola, Fábrica de Aceites La Central SA de CV, Guadalajara, Jalisco, Mexico.

${ }^{\mathrm{d}}$ The husk of the maize cob was ground, autoclaved and sieved through a kitchen sieve with a 1.2-mm aperture wire mesh.

${ }^{\mathrm{e}}$ Synthetic silica filler, Crosfield Chemical Group, Warrington, UK.

${ }^{\mathrm{f}}$ Costs based on purchase in Tapachula, Chiapas, Mexico from bulk distributors, assuming an exchange rate of US\$1 $=9.1 \mathrm{Mexican}$ Pesos.
}

plant, respectively. There were 10 replicate blocks assigned to each treatment.

Granules were applied by sprinkling into the developing leaf whorl using calibrated spoons made from $1.5 \mathrm{ml}$ plastic microcentrifuge tubes cut to three different sizes and attached to wire handles. Calibration of the spoons using a laboratory balance indicated that they gave consistent delivery of granules with low variability in weights (means \pm SE: $0.15 \pm 0.004,0.45 \pm 0.006$, $0.80 \pm 0.097 \mathrm{~g}, N=30$ in each case). Eight counts were performed on 25 plants at eight different locations within the maize plot to determine the degree of natural infestation by $S$. frugiperda larvae at the start of the experiment.

At 2, 5, and 7 days postapplication, 10 randomly selected plants from each block were cut, placed in plastic bags, and transported to the laboratory, where $S$. frugiperda larvae were transferred to individual plastic cups containing semi-synthetic diet and reared to death or pupation. Viral infection and parasitoid emergence were noted as mentioned in the section on comparison of spray and granule formulations.

Percentage virus mortality data were $\operatorname{arcsine}(\sqrt{ } x)$ transformed and subjected to repeated measures analysis in SAS (SAS Institute, 1992) with the mortality of larvae collected at 2, 5, and 7 days postapplication as dependent variables. Tests of sphericity were performed using Mauchly's criterion. The significance of treatment and time effects were interpreted in terms of $F$ statistics generated from Pillai's trace (Winer, 1971).

\subsection{Persistence of inoculum on maize plants}

In a separate part of the maize field used for the field trial on application rate of granules, four rows of maize plants approximately $1 \mathrm{~m}$ tall (late-whorl stage) were sprayed with an aqueous suspension of $20 \mathrm{ppm}$ Spinosad
(Tracer, Dow AgroSciences) in an attempt to eliminate infestation by $S$. frugiperda larvae. Each row of plants was divided into blocks of $30 \mathrm{~m}$ with $5 \mathrm{~m}$ between blocks and was $30 \mathrm{~m}$ distance from any other treated row. Within each block, 40 experimental plants were randomly selected at distances of $60-100 \mathrm{~cm}$ and labeled around the base using yellow plastic tape.

Six days later, plants were treated with $3.75 \times$ $10^{7} \mathrm{OBs} /$ plant either in $7.5 \mathrm{ml}$ of an aqueous spray with $0.02 \%$ Agral Plus (Zeneca) as wetter-sticker or the same quantity of virus in $0.6 \mathrm{~g}$ of granules/plant (recipe E). These treatments represented the equivalent of $1.8 \times 10^{12} \mathrm{OBs} / \mathrm{ha}$ in 300 liters water (spray application) or $24 \mathrm{~kg} / \mathrm{ha}$ granules. Spray applications were applied using a manual backpack sprayer fitted with a cone nozzle. Granular applications were sprinkled over the whorl of the maize plant using a plastic pot with a perforated lid, calibrated to deliver $0.6 \pm 0.01 \mathrm{~g}$ (mean $\pm \mathrm{SE}, N=30$ ) of granules. To estimate the activity of the different treatments within $2 \mathrm{~h}$ following applications, groups of 10 late second-instar S. frugiperda were inoculated onto eight of the marked plants in each block, except the untreated control. After $24 \mathrm{~h}$, these plants were cut, placed individually in labeled plastic bags and transported to the laboratory where each plant was dissected. Any late second- or early third-instar larvae found were recorded, individually transferred to plastic cups containing semi-synthetic diet and reared at $25 \pm 1{ }^{\circ} \mathrm{C}$ until pupation or death. There were two controls; a virus control that was not treated with virus and an infestation control that was not treated by virus and that was not artificially infested with $S$. frugiperda larvae. The uninfested control was used to estimate the residual natural infestation of $S$. frugiperda larvae that survived the Spinosad treatment, or re-infested the plants during the experimental period, to demonstrate that almost all 
larvae recovered during the experiment originated from the artificial infestation and, as such, had only been exposed to contaminated foliage for a 24-h period.

In this way, viral activity and the prevalence of parasitism were determined at $0-24 \mathrm{~h}$ postapplication. The process was repeated at $1-2,2-3,4-5$, and 7-8 days postapplication. Therefore, this experiment differed from those reported previously in that larvae were only exposed to residual inoculum on treated plants for periods of $24 \mathrm{~h}$ before being collected and reared to determine the prevalence of viral infection.

To ensure that residues of Spinosad did not affect this trial, a sample of 30 plants that had been sprayed 6 days previously with $20 \mathrm{ppm}$ Spinosad were cut and transported to the laboratory. Two pieces of developing leaf whorl $\left(\sim 12 \mathrm{~cm}^{2}\right.$ area), representing the normal feeding site of $S$. frugiperda larvae, were taken from each plant and placed in $10 \mathrm{~cm}$ diameter plastic petri dishes with groups of five second-instar $S$. frugiperda for a period of $24 \mathrm{~h}$ at $25 \pm 1^{\circ} \mathrm{C}$. After that time, larvae were transferred individually to $25 \mathrm{ml}$ plastic cups containing semisynthetic diet. The mortality of these larvae was determined $72 \mathrm{~h}$ later. The process was repeated for an equal number of control plants that had not been treated with Spinosad $(N=600$ larvae in total).

To ensure that the susceptibility of different cohorts of larvae used to infest experimental plants did not change markedly during the trial, the larvae left over from each infestation were individually placed in $25 \mathrm{ml}$ plastic cups containing $7.5 \times 10^{7} \mathrm{OBs} / \mathrm{g}$ of diet. After $24 \mathrm{~h}$ exposure, larvae were individually transferred to uncontaminated diet and reared to pupation or death. Control larvae were treated identically but were not exposed to virus. There were between 3 and 5 replicates each of 25 larvae for each day of the experiment.
The arcsine transformed percentage prevalence of virus infection in each cohort of larvae from the field experiment was subjected to repeated measures ANOVA using SAS (SAS Institute, 1992), as described above. The prevalence of mortality of larvae tested in the laboratory was analyzed in GLIM using a binomial error structure and the model checking macro present in this package.

\section{Results}

\subsection{Palatability of phagostimulant mixtures}

Granule recipe had a significant effect on virus induced mortality $\left(F_{9,20}=2.64, P<0.05\right.$, scale parameter $=1.37)$ and time to death $\left(F_{9,1172}=15.2, P<0.001\right)$ of inoculated larvae (Table 2). Mortality was $93-94 \%$ in larvae exposed to diet and recipes $\mathrm{A}$ and $\mathrm{B}$ but was significantly reduced in larvae exposed to recipes $\mathrm{C}, \mathrm{D}$, $\mathrm{G}, \mathrm{H}$, and I. There was no mortality of control larvae. The mean time to death was similar among all treatments, with the exception of recipe $\mathrm{B}$ and recipe $\mathrm{I}$ in which larvae showed significantly longer times to death (Table 2).

When the observed mortality was divided by the cost of each granular formulation (ingredients alone, excluding cost of virus), it was apparent that recipes $\mathrm{A}$ and $\mathrm{B}$ caused the highest prevalence of infection, whereas recipes $\mathrm{E}$ and $\mathrm{F}$ offered the greatest mortality per unit cost. However, the time to death of larvae offered recipe $\mathrm{B}$ was extended whereas the time to death of larvae exposed to virus in granule recipes $\mathrm{A}, \mathrm{E}$, and $\mathrm{F}$ were similar to that of larvae exposed to virus in diet (Table 2). Preliminary trials involving application of these formulations to maize plants indicated that formulation

Table 2

Total mortality, mean time to death, and mortality-cost relationship following $24 \mathrm{~h}$ exposure to nine granular formulations of SfMNPV and virus incorporated into semi-synthetic diet

\begin{tabular}{|c|c|c|c|}
\hline Formulation & Total mortality $(\%)^{\mathrm{a}}$ & Mean time to death $\pm \mathrm{SE}(\mathrm{h})^{\mathrm{a}}$ & Percent mortality/US\$ cost $\mathrm{b}^{\mathrm{b}}$ \\
\hline Diet & $93.4 \mathrm{a}$ & $159.3 \pm 3.1 \mathrm{a}$ & - \\
\hline Recipe $A^{c}$ & $93.5 \mathrm{a}$ & $165.5 \pm 2.8 \mathrm{a}$ & 1.38 \\
\hline Recipe B & $94.8 \mathrm{a}$ & $186.4 \pm 4.7 b$ & 1.32 \\
\hline Recipe D & $85.7 \mathrm{~b}$ & $168.5 \pm 4.3 \mathrm{a}$ & 0.83 \\
\hline Recipe $\mathrm{E}^{\mathrm{c}}$ & $90.2 \mathrm{ab}$ & $159.2 \pm 3.0 \mathrm{a}$ & 1.80 \\
\hline Recipe F & $87.0 \mathrm{ab}$ & $161.7 \pm 3.1 \mathrm{a}$ & 1.89 \\
\hline Recipe I & $83.2 b$ & $211.6 \pm 9.3 \mathrm{c}$ & 0.79 \\
\hline
\end{tabular}

${ }^{\mathrm{a}}$ Figures followed by the same letter were not significantly different for comparison within each column (mortality data analyzed in GLIM: binomial error distribution with scale parameter specified as 1.37 , time to death data analyzed by $t$ test on $\log _{\mathrm{e}}$ transformed time to death performed in GLIM, $P<0.05$ ).

${ }^{\mathrm{b}}$ Cost of each granular recipe given in Table 1 .

${ }^{\mathrm{c}}$ Recipes $\mathrm{A}$ and $\mathrm{E}$ used in comparison of efficacy of spray and granular formulations. Recipe $\mathrm{E}$ used in studies on application rates and persistence of formulation on leaf surfaces. 
F did not adhere well to plant surfaces and was quickly washed away by afternoon rainstorms (data not shown). Therefore, trials comparing the efficacy of spray and granular formulations were performed using granule recipes $\mathrm{A}$ and $\mathrm{E}$. Formulation $\mathrm{E}$ was subsequently studied in detail.

\subsection{Comparison of spray and phagostimulant formula- tions}

Multiple linear regression analysis of the percentage infection observed in larvae collected at 1-10 days postapplication and reared in the laboratory until death or pupation revealed a significant positive relationship between prevalence of infection and quantity of inoculum applied for both granular and spray formulations (Fig. 1A and B). A significant negative relationship between prevalence of infection and interval between application and sampling of larvae was also detected for both types of formulation. For spray formulation, the relationship was best described by the equation

$y=17.113 \log [$ dose $]-2.988[$ day $]-179.9$

$\left(R^{2}=0.77, P<0.001\right)$,

where $y$ was the percentage mortality due to virus infection, dose was the application rate of virus (OBs/ha) and day was the interval between application and sampling. The multiple regression equation for granular formulation was

$y=30.721 \log [$ dose $]-2.836[$ day $]-326.7$

$\left(R^{2}=0.47, P<0.001\right)$.

This demonstrates that virus-induced mortality was greater when inoculum was applied in granular than in spray formulation regression coefficient $\pm \mathrm{SE}$ for $\log [$ dose] was $17.11( \pm 4.15)$ for spray vs. $30.72( \pm 6.81)$ for granular formulation) (Fig. 1A and B; Table 3).

The prevalence of infection was not sensitive to sample size (number of larvae collected at each timepoint) for either spray (regression coefficient $=0.036$, $t_{25}=1.24, P=0.22$ ) or granular formulations (regression coefficient $=0.006, t_{29}=0.14, P=0.89$ ). The mean prevalence of viral infection in larvae recovered from control plots was $<1 \%$ in spray treated plots and $<0.1 \%$ in larvae from granule treated plots.

The mean prevalence of parasitoid emergence was $23.1 \%$ in larvae exposed to spray formulation and $20.3 \%$ in larvae exposed to granular formulation of virus. The prevalence of parasitism was not affected by the quantity of viral inoculum or the interval between application and sampling of larvae for either type of formulation $\left(F_{3,23}=0.46, P=0.71 \quad\right.$ for $\quad$ spray formulation; $F_{3,29}=0.82, P=0.49$ for granular formulation).

Multiple linear regression performed using the results of both types of formulation confirmed the greater ac-
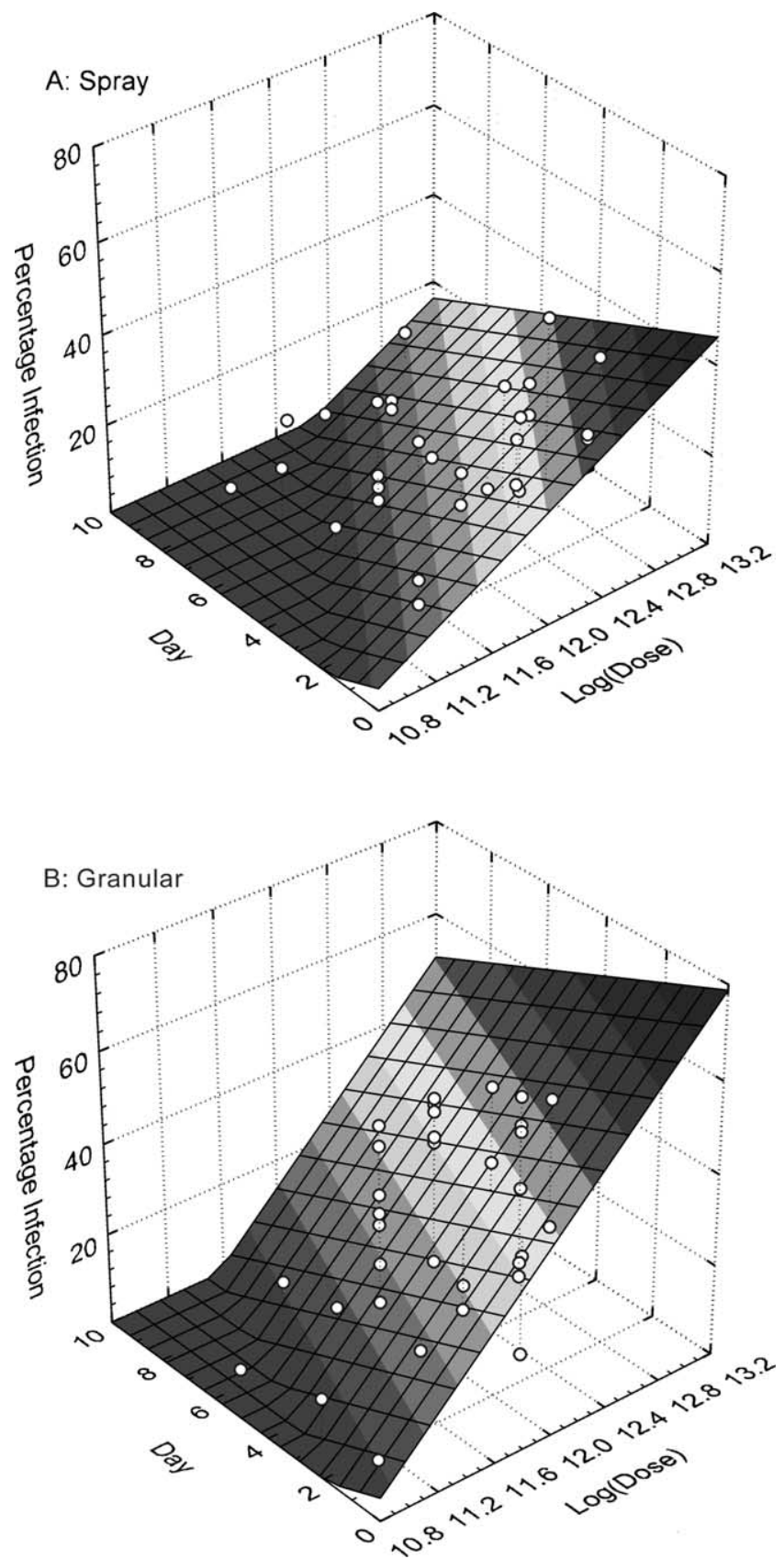

Fig. 1. Multiple linear regression of percentage prevalence of infection on $\log$ virus application rate and interval between application and sampling for virus applied as (A) an aqueous spray, or (B) in a phagostimulant granular formulation.

tivity of inoculum applied in granular formulation. The regression equation was:

$y=23.638 \log [$ dose $]-3.172[$ day $]$

$$
+13.211 \text { [formulation] }-253.6 \quad\left(R^{2}=0.55, P<0.001\right),
$$

where [formulation] was assigned a value of zero for spray and 1 for granular formulation (SE of regression $\quad$ coefficient $=3.2, \quad t_{59}=4.11, P<0.001$ ) (Table 3). 
Table 3

ANOVA of the multiple linear regression of percentage prevalence of infection on $\log$ virus application rate and interval between application and sampling for virus applied as an aqueous spray or in a granular formulation, or as both formulations taken together

\begin{tabular}{lrrrl}
\hline Source & $\begin{array}{c}\text { Sum of } \\
\text { squares }\end{array}$ & df & $\begin{array}{l}\text { Mean } \\
\text { square }\end{array}$ & \multicolumn{1}{l}{$F$} \\
\hline $\begin{array}{l}\text { Spray formulation } \\
\text { Regression }\end{array}$ & 4817 & 4 & 1204 & $21.1^{* * *}$ \\
$\begin{array}{l}\text { Residual } \\
\text { Total }\end{array}$ & 1425 & 25 & 57 & \\
Granular formulation & 6242 & & & \\
Regression & 5310 & 3 & 1770 & $8.7^{* * *}$ \\
$\begin{array}{l}\text { Residual } \\
\text { Total }\end{array}$ & 5880 & 29 & 938 & \\
Both types formulation & 11,190 & & & \\
Regression & 10,706 & 4 & 2676 & $18.1^{* * *}$ \\
Residual & 8747 & 59 & 148 & \\
Total & 19,453 & & & \\
\hline$* * *$ \\
$P<0.001$. & & & & \\
& & & &
\end{tabular}

\subsection{Application rate for phagostimulant granules}

Application of virus caused a significant increase in the prevalence of total $S$. frugiperda mortality (parasitism + viral infection) in larvae collected at $2\left(F_{3,36}=\right.$ 23.8, $P<0.001), 5\left(F_{3,36}=3.11, P=0.04\right)$, and 7 days $\left(F_{3,36}=3.74, P=0.02\right)$ postapplication and reared in the laboratory until death or pupation (Fig. 2). Virusinduced mortality of $S$. frugiperda larvae declined significantly during the experiment from approximately
$60 \%$ in larvae collected at 2 days postapplication to $30 \%$ in larvae collected at 7 days postapplication $\left(F_{2,35}=18.3, P<0.001\right)$. The quantity of granules applied did not significantly affect viral mortality at any timepoint (comparison 2-5 days: $F_{3,36}=2.48, P=0.08$; comparison 5-7 days: $F_{3,36}=1.05, P=0.38$ ). No baculoviral infections were observed in larvae collected in control plots. In contrast, parasitoid emergence increased significantly in all treatments during the experiment $\left(F_{2,35}=16.0, P<0.001\right)$ but was generally higher in control larvae than in larvae collected from plants treated with virus (Fig. 2). The majority of emerging parasitoids were either the egg-larval braconid, Chelonus insularis Cresson (81\%), or the solitary ichneumonid Pristomerus spinator (F.) (13\%) that parasitizes thirdand fourth-instar $S$. frugiperda. Because percentage parasitism increased during the experiment whereas the prevalence of virus infection decreased, total mortality (virus infection + parasitism) did not change significantly during the experiment in any treatment and varied from $65-81 \%$ in larvae recovered from virus-treated plots (repeated measures comparison $2-5$ days: $F_{3,36}=$ $2.48, P=0.08$; comparison $5-7$ days: $F_{3,36}=1.05$, $P=0.38$; Fig. 2).

\subsection{Persistence of inoculum on maize plants}

Recovery of larvae from artificially infested plants was $4.2 \pm 0.15$ larvae/plant (mean $\pm \mathrm{SE}$ and did not

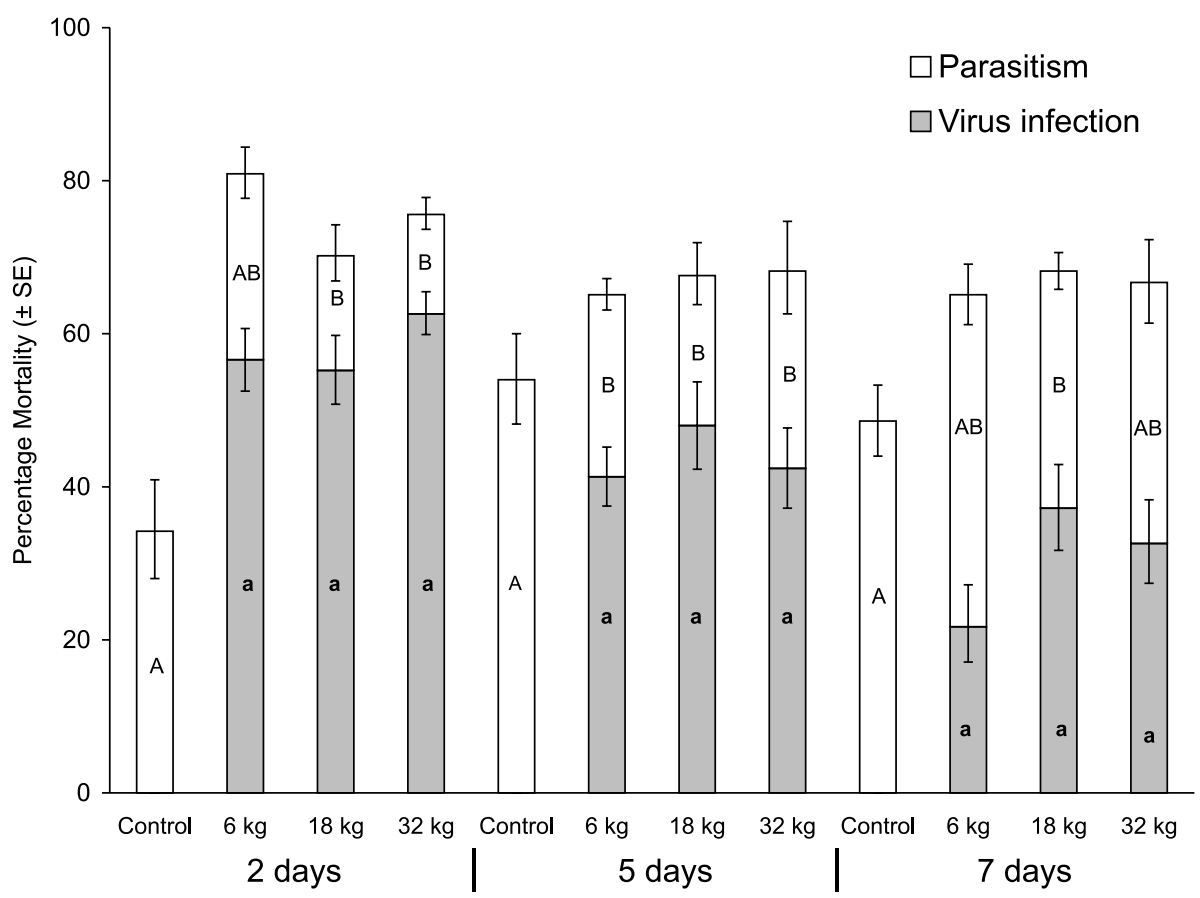

Fig. 2. Effect of applying $1.5 \times 10^{12} \mathrm{OBs} / \mathrm{ha}$ of SfMNPV in 6 , 18, or $32 \mathrm{~kg} / \mathrm{ha}$ of phagostimulant granules on the prevalence of virus infection (gray columns) and parasitoid emergence (white columns) in Spodoptera frugiperda larvae collected at 2, 5, and 7 days postapplication and reared in the laboratory. Columns labeled with different letters indicate significant differences for comparison within a sample: upper case letters refer to parasitism, lower case letters refer to virus infection (ANOVA, $P<0.05$ ). See text for repeat measures analysis for comparisons between sample timepoints. 


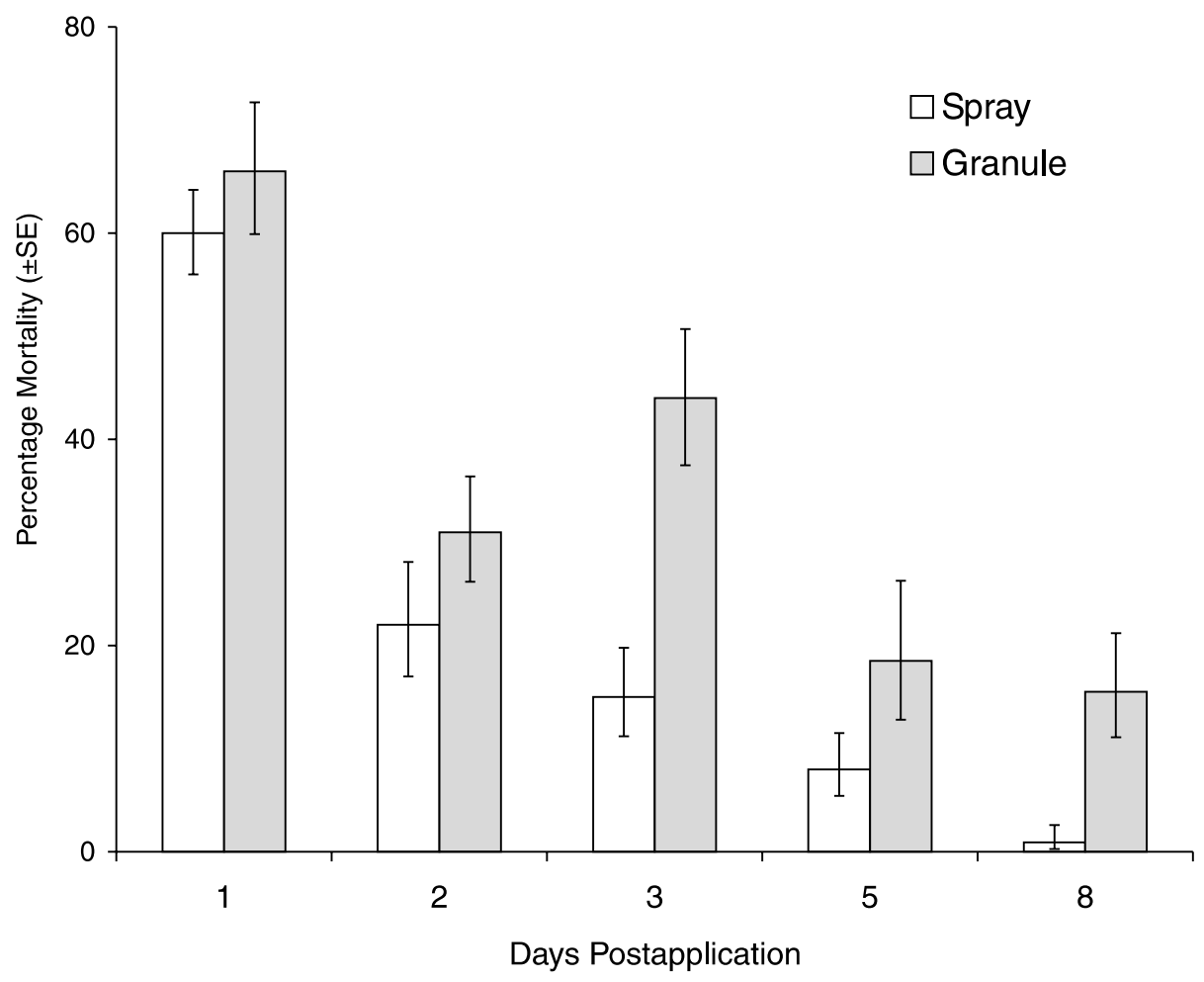

Fig. 3. Percentage virus mortality of Spodoptera frugiperda larvae inoculated onto plants that had been treated with $3.75 \times 10^{7} \mathrm{OBs} / \mathrm{plant}$ in spray (white columns) or granular (gray columns) formulations. Larvae were exposed for a $24-\mathrm{h}$ period at $0-1,1-2,2-3$ days, etc. postapplication and then reared in the laboratory until pupation or death. Larvae collected from control plants suffered no virus mortality.

differ significantly among treatments $\left(F_{2,475}=2.14\right.$, $P>0.05$ ). Recovery of $S$. frugiperda larvae from uninfested control plants was extremely low $(0.06 \pm 0.02$ larvae/plant) indicating that the vast majority of larvae had only been exposed to viral inoculum for the 24-h period between infestation and recovery. The activity of SfMNPV in aqueous spray or granular formulations fell significantly during the 8 day experimental period $\left(F_{4,24}=35.8, P<0.001\right)$ (Fig. 3$)$. It was clear, however, that persistence of activity of viral inoculum during the experiment was significantly greater when applied in the granular formulation compared to the spray formulation $\left(F_{1,6}=23.0, P=0.003\right)$. For example, at 8 days postapplication, viral inoculum applied as granules caused $16 \%$ infection in larvae inoculated onto treated plants for a period of $24 \mathrm{~h}$, whereas virus mortality was less than $1 \%$ in larvae inoculated onto plants treated with the spray formulation (Fig. 3). No viral infections were observed in larvae from artificially infested control plants indicating that the natural prevalence of SfMNPV on experimental plants was negligible. Emergence of parasitoids from larvae was very low $(0.8-2.3 \%$ of the total number of larvae recovered at each sample point), probably due to the short period ( $24 \mathrm{~h}$ ) for which larvae were available for parasitism during the trial.

Larvae offered pieces of maize whorl leaves that had been sprayed 6 days previously with $20 \mathrm{ppm}$ Spinosad suffered just $3 \%$ mortality at $72 \mathrm{~h}$ postinoculation whereas larvae exposed to leaf pieces from untreated control plants suffered no mortality during the same period. Consequently, elimination of the natural $S$. frugiperda infestation of experimental plants by Spinosad treatment was unlikely to have meaningfully affected the recovery of experimental $S$. frugiperda larvae during the course of the trial. When exposed to virus in the laboratory, the average mortality of batches of larvae inoculated on to plants during the experiment was $54.1 \%$ (range of SE: $50.8-57.3 \%$ ) and this did not change significantly at any timepoint $\left(F_{4,14}=1.87, P>0.05\right.$, scale parameter $=1.86$ ) indicating that the susceptibility of different batches of $S$. frugiperda larvae to viral infection was essentially constant during the trial.

\section{Discussion}

Formulation of insect pathogens is recognized as one of the most important priorities in biopesticide research, especially for developing countries (Harris and Dent, 2000). It is well established that the efficacy of entomopathogens that act by ingestion can be improved by the use of formulations that include feeding stimulants which increase the consumption of the pathogen resulting in enhanced prevalence of disease and improved pest control (Bell and Kanavel, 1977; Farrar and Ridgway, 1994). In this respect, the use of flour- and 
starch-based granular formulations (Dunkle and Shasha, 1988; Gillespie et al., 1994; McGuire et al., 1990) has been the subject of recent interest for the delivery of B. thuringiensis and nucleopolyhedroviruses to noctuid pests (Morales-Ramos et al., 1998; Tamez-Guerra et al., 1998, 2000a, 2000b). One drawback of phagostimulant formulations is that they are invariably more expensive than simpler water-based sprays. However, the use of granular feeding stimulants has a number of advantages that may compensate for the increased formulation cost. These include the ability to use a lower quantity of pathogen inoculum to achieve satisfactory pest control (Bartelt et al., 1990) and the ability to target applications precisely to the feeding site of the pest (e.g., application of granules directly to the maize leaf whorl) (McGuire et al., 1994). Moreover, the opacity of granules may protect the pathogen from UV degradation (Bartelt et al., 1990) and may improve the rainfastness of the application (McGuire et al., 1996; Tamez-Guerra et al., 2000a,b).

In the present study we tested nine granule recipes for NPV formulation. Recipe E was identified as highly palatable to $S$. frugiperda larvae and, at a cost US\$0.50/ $\mathrm{kg}$, was considerably cheaper than granule recipe A (US $\$ 0.68 / \mathrm{kg}$ ) used in previous field trials (Cisneros et al., 2002a,b). Recipe E was also more palatable and cheaper than recipe $\mathrm{G}$, presumably because of the higher flour and lower starch content of recipe E. Maize flour contains protein, an established phagostimulant (Bartelt et al., 1990), and costs about US\$0.38/ $\mathrm{kg}$ in Mexico. Cornstarch, however, contains no protein and is about five times more expensive than maize flour. Recipes that contained a synthetic silica filler or a high concentration $(25 \%)$ of ground maize cob (recipes I and B) were the least palatable of the recipes tested. Preliminary observations also indicated that granules containing $20 \%$ or more ground maize cob tended to disintegrate and were washed off the plant when exposed to heavy tropical rainstorms, whereas granules containing greater proportions of starch or pregelatinized flour turned into a paste and adhered well to plant foliage despite heavy rain.

Multiple linear regression analysis of a total of 15 independent field trials involving application of SfMNPV in aqueous spray or granular formulations demonstrated that virus delivered in phagostimulant granules resulted in a consistently higher prevalence of infection than the equivalent quantities of inoculum applied as aqueous sprays (Fig. 1A and B). Natural parasitism contributed an average of $20-23 \%$ mortality and was not significantly affected by virus application rate or the interval between application and sampling. A lack of correlation between virus mortality and parasitism was reported previously in a simple analysis of the efficacy of spray applications of SfMNPV for S. frugiperda control in field trials performed in Mexico and
Honduras (Martínez et al., 2000). Virus application, however, caused a significant decrease in the prevalence of parasitoid emergence in the field experiment on the quantity of granule applications. This may be a consequence of the high prevalence of parasitism (mean 45\%) that was observed during this field trial which was double the mean prevalence observed in the experiments used to compare spray and granular formulations of SfMNPV by multiple regression analysis. Natural variation in field data may reduce the probability of virusparasitoid interference being detected by conventional statistical techniques when the prevalence of parasitism or virus infection is low.

The relationship between pathogen concentration and volume of application appears be highly influenced by delivery. In general, for spray applications, greater pest control is observed with high droplet density requiring high volume applications. Conversely, pathogens delivered with feeding stimulants may function more effectively if the application volume is reduced and the concentration of the pathogen increased (HunterFujita et al., 1998; Williams and Cisneros, 2001). Control of Helicoverpa zea (Boddie) on cotton was improved by using low droplet density of the gustatory stimulant Coax, but a high concentration of viral OBs per droplet (Stacey et al., 1977). On the other hand, a B. thuringiensis formulation based on clay granules for control of Ostrinia nubilalis (Hübner) was more effective at high pathogen concentrations, but the volume of the application had little effect on control (Lynch et al., 1977).

In our study, in which $1.5 \times 10^{12} \mathrm{OBs} /$ ha were formulated into 6,18 , or $32 \mathrm{~kg} / \mathrm{ha}$ of granules, it was apparent that small quantities of highly concentrated inoculum $\left(2.5 \times 10^{11} \mathrm{OBs} / \mathrm{kg}\right)$ caused a similar prevalence of infection as large quantities of less concentrated inoculum $\left(4.6 \times 10^{10} \mathrm{OBs} / \mathrm{kg}\right)$, perhaps because both of these concentrations caused high mortality $(>90 \%)$ in larvae exposed in the laboratory. The maize leaf whorl is a complex structure comprising overlapping spirals of developing leaves in which the larvae of $S$. frugiperda feed. Consequently, we had expected that larger quantities of granules would achieve a greater coverage within the whorl and therefore cause a higher prevalence of infection, but this was not the case. Moreover, it was mechanically difficult to apply very small quantities of granules in the field.

Resource poor maize farmers in Mesoamerica are accustomed to applying granular chemical insecticides by hand by sprinkling a pinch of granules to the leaf whorl of each plant. Gloves or other forms of skin protection are rarely, if ever, used. The recommended application rate for such granular chemical insecticides is usually about $10 \mathrm{~kg} / \mathrm{ha}$, and this seems to be a realistic lower limit for manual application of granular products to maize. Tamez-Guerra et al. (1998) also report applying a maize flour based granular formulation of 
B. thuringiensis at a rate of $10 \mathrm{~kg} / \mathrm{ha}$ for the control of Spodoptera spp. in maize.

The cost of $10 \mathrm{~kg}$ of granular recipe E would be US $\$ 5.00$ for the ingredients alone. The cost of producing $1.5 \times 10^{12} \mathrm{OBs}$ of virus on a laboratory scale in Mexico was recently estimated at US\$12.10 (Williams et al., 1999) giving a total cost for the virus + formulation ingredients of about US\$17. Large-scale production of virus is likely to be cheaper than laboratory scale production leading to a lower cost bioinsecticide, but these calculations do not include the commercial costs involved in marketing, distribution, overheads, etc.

An additional indirect benefit to the use of phagostimulant formulations is that they may attract natural enemies resulting in an increased abundance of predatory activity in the treated crop (Carlson and Chang, 1973; Evans and Swallow, 1993). Application of sugar solutions to maize in Honduras resulted in an increase in the abundance of ants and tachinid parasitoids leading to an $18 \%$ reduction in $S$. frugiperda infestation and a $35 \%$ reduction in plant damage compared to control plots sprayed with water (Cañas and O'Neil, 1998). In our study, the attractiveness of the maize flour granules to fire ants (Solenopsis spp.) was observed many times but the abundance of ants in experimental plots was low and recovery of $S$. frugiperda larvae did not differ significantly between control and granule-treated plots.

As expected, viral inoculum applied in maize flour granules showed significantly greater activity, approximately $23 \%$ of the original activity remaining, at 8 days postapplication, whereas the activity of virus applied in aqueous spray had fallen to virtually zero. Rainfall occurred every afternoon during the experimental period. This serves to emphasize that maize flour formulation not only increases the instantaneous probability of infection at one moment in time, but also the cumulative probability of infection over time. The efficacy of pest control may be further enhanced by incorporating viral synergists or UV protectant substances into phagostimulant formulations. Field tests of SfMNPV formulated into phagostimulant granules resulted in approximately $20 \%$ higher prevalence of infection when boric acid was included in the formulation (Cisneros et al., 2002b).

Recentstudieson Anagraphafalcifara (Kirby)AfMNPV formulatedwithmaizeflourandpotassiumlignateindicated that this formulation retained more than half its original activityfollowingsimulated rainfall, andalmostfullactivity following $8 \mathrm{~h}$ of simulated sunlight (Tamez-Guerra et al., 2000a). Field tests on cowpea confirmed the superior persistence of the maize flour + lignate formulation when bioassayed in $H$. zea larvae. In contrast, the optical brightener Blankophor BBH provided significantly less solar UV protection than did lignate, possibly because of an interaction with calcium ions present in the formulation that may have deactivated the optical brightener. Lignin is a cheap and readilyavailablenaturalproduct thatmeritsfurtherstudyas a biopesticide adjuvant (Tamez-Guerraetal.,2000a).

In conclusion, the efficacy of SfMNPV was improved by formulation as a maize flour based granule that could be applied directly into the maize leaf whorl. The granular formulation caused a higher prevalence of infection in $S$. frugiperda larvae and persistence longer on crop foliage compared to an aqueous spray application. The cost of the ingredients for the formulation was approximately US $\$ 5 /$ ha (not including the virus component). The efficacy of the formulation may be further enhanced by incorporating viral potentiating substances into the granules. This type of formulation may also be useful for the delivery of other biological insecticides that act by ingestion.

\section{Acknowledgments}

We thank Jaime Jiménez, Anaximandro Gómez, Maurilio López, and Walter Méndez for valuable assistance in the field trial. Gerardo Hernández kindly supplied ground maize cobs for the study. Patricia Támez gave helpful comments on aspects of this work. Funding came from SIBEJ-0501047, a British Council link exchange program and via a CONACyT student grant to V. Castillejos.

\section{References}

Bartelt, R.J., McGuire, M.R., Black, D.A., 1990. Feeding stimulants for the European corn borer (Lepidoptera: Pyralidae): additives to a starch-based formulation for Bacillus thuringiensis. Environ. Entomol. 19, 182-189.

Bell, M.R., Kanavel, R.F., 1977. Field tests of a nuclear polyhedrosis virus in a bait formulation for control of pink bollworm and Heliothis spp. in cotton in Arizona. J. Econ. Entomol. 70, 625-629.

Cañas, L.A., O'Neil, R.J., 1998. Applications of sugar solutions to maize, and the impact of natural enemies on fall armyworm. Int. J. Pest Manag. 44, 59-64.

Carlson, R.E., Chang, H.C., 1973. Reduction of Ostrinia nubilalis population by predatory insects attracted by sucrose sprays. Entomophaga 18, 205-211.

Cisneros, J., Goulson, D., Derwent, L.C., Penagos, D., Hernández, O., Williams, T., 2002a. Toxic effects of Spinosad on predatory insects. Biol. Contr. 23, 156-163.

Cisneros, J., Pérez, J.A., Penagos, D., Ruiz, V.J., Goulson, D., Caballero, P., Cave, R.D., Williams, T., 2002b. Formulation of a baculovirus with boric acid for control of Spodoptera frugiperda (Lepidoptera: Noctuidae) in maize. Biol. Contr. 23, 87-95.

Crawley, M.J., 1993. GLIM for Ecologists. Methods in Ecology Series. Blackwell, Oxford, UK.

Dunkle, R.L., Shasha, B.S., 1988. Starch-encapsulated Bacillus thuringiensis: a potential new method for increasing environmental stability of entomopathogens. Environ. Entomol. 17, 120-126.

Escribano, A., Williams, T., Goulson, D., Cave, R.D., Chapman, J.W., Caballero, P., 1999. Selection of a nucleopolyhedrovirus for control of Spodoptera frugiperda (Lepidoptera: Noctuidae): structural, genetic and biological comparison of four isolates from the Americas. J. Econ. Entomol. 92, 1079-1085. 
Evans, E.W., Swallow, J.G., 1993. Numerical response of natural enemies to artificial honeydew in Utah alfalfa. Environ. Entomol. 22, 1392-1401.

Farrar, R.R., Ridgway, R.L., 1994. Comparative studies of the effects of nutrient based phagostimulants on six lepidopterous insect pests. J. Econ. Entomol. 87, 44-52.

Farrar, R.R., Ridgway, R.L., 1998. Quantifying time-mortality relationships for nuclear polyhedrosis viruses when survivors are present. Environ. Entomol. 27, 1289-1296.

Gillespie, R.L., McGuire, M.R., Shasha, B.S., 1994. Palatability of flour granular formulations to European corn borer larvae (Lepidoptera: Pyralidae). J. Econ. Entomol. 87, 452-457.

Harris, J., Dent, D., 2000. Priorities in Biopesticide Research and Development in Developing Countries. CABI Publishing, Wallingford, UK.

Hruska, A.J., Gould, F., 1997. Fall armyworm (Lepidoptera: Noctuidae) and Diatraea lineolata (Lepidoptera: Pyralidae): impact of larval population level and temporal occurrence on maize yield in Nicaragua. J. Econ. Entomol. 90, 611-622.

Hunt, L.M., Ojanguren, R., Schwartz, N., Halperin, D., 1999. Balancing risks and resources: applying pesticides without safety equipment in Southern Mexico. In: Hahn, R. (Ed.), Anthropology in Public Health. Oxford University Press, Oxford, UK, pp. 265-289.

Hunter-Fujita, F.R., Entwistle, P.F., Evans, H.F., Crook, N.E., 1998. Insect Viruses and Pest Management. Wiley, Chichester, UK.

Jones, K.A., Cherry, A.J., Grzywacz, D., 1997. Formulation: is it an excuse for poor application? In: Evans, H.F. (Ed.), Microbial Insecticides: Novelty or Necessity? Proc. Brit. Crop Prot. Council No. 68, Farnham, UK, pp. 11-19.

Jones, K.A., Burges, H.D., 1998. Formulation of bacterial, viruses and protozoa to control insects. In: Burges, H.D. (Ed.), Formulation of Microbial Biopesticides: Beneficial Micro-organisms, Nematodes and Seed Treatments. Kluwer Academic Publishers, Dordrecht, Netherlands, pp. 32-127.

Lynch, R.E., Lewis, L.C., Berry, E.C., Robinson, J.F., 1977. European corn borer: granular formulations of Bacillus thuringiensis for control. J. Econ. Entomol. 70, 389-391.

Martínez, A.M., Goulson, D., Chapman, J.W., Caballero, P., Cave, R.D., Williams, T., 2000. Is it feasible to use optical brightener technology with a baculovirus bioinsecticide for resource-poor maize farmers in Mesoamerica? Biol. Contr. 17, 174-181.

McConnell, R., Hruska, A., 1993. An epidemic of pesticide poisoning in Nicaragua: implications for prevention in developing countries. Am. J. Pub. Health 83, 1559-1562.

McGuire, M.R., Shasha, B.S., Eastman, C.E., Oloumi-Sadeghi, H., 1996. Starch and flour-based sprayable formulations: effect on rainfastness and solar stability of Bacillus thuringiensis. J. Econ. Entomol. 89, 863-869.

McGuire, M.R., Shasha, B.S., Lewis, L.C., Bartelt, R.J., Kinney, K., 1990. Field evaluation of granular starch formulations of Bacillus thuringiensis against Ostrinia nubilalis (Lepidoptera: Pyralidae). J. Econ. Entomol. 83, 2207-2210.
McGuire, M.R., Shasha, B.S., Lewis, L.C., Nelsen, T.C., 1994. Residual activity of granular starch-encapsulated Bacillus thuringiensis. J. Econ. Entomol. 87, 631-637.

Mihm, J.A., 1984. Técnicas Eficientes Para la Crianza Masiva e infestación de Insectos, en la Selection de las Plantas Hospedantes para Resistencia al Gusano Cogollero, Spodoptera frugiperda. Centro Internacional de Mejoramiento de Maíz y Trigo (CIMMYT), El Batán, Mexico.

Morales-Ramos, L.H., McGuire, M.R., Galán-Wong, L.J., 1998. Utilization of several biopolymers for granular formulations of Bacillus thuringiensis. J. Econ. Entomol. 91, 1109-1113.

Numerical Algorithms Group. 1993. In: Francis, B., Green, M., Payne, C. (Eds.), The GLIM System: Release 4 Manual. Oxford University Press, Oxford, UK.

SAS Institute, 1992. SAS User's Guide, Version 6.04. SAS Institute, Cary, NC.

Sokal, R.R., Rohlf, F.J., 1981. Biometry, second ed. W.H. Freeman, New York

Stacey, A.L., Yearian, W.C., Young, S.Y., 1977. Evaluation of Baculovirus heliothis with feeding stimulants for control of Heliothis larvae on cotton. J. Econ. Entomol. 70, 779-784.

Tamez-Guerra, P., Castro-Franco, R., Medrano-Roldán, H., McGuire, M.R., Galán-Wong, L.J., Luna-Olvera, H.A., 1998. Laboratory and field comparisons of strains of Bacillus thuringiensis for activity against noctuid larvae using granular formulations (Lepidoptera). J. Econ. Entomol. 91, 86-93.

Tamez-Guerra, P., McGuire, M.R., Behle, R.W., Hamm, J.J., Sumner, H.R., Shasha, B.S., 2000a. Sunlight persistence and rainfastness of spray-dried formulations of baculovirus isolated from Anagrapha falcifara (Lepidoptera: Noctuidae). J. Econ. Entomol. 93, 210-218.

Tamez-Guerra, P., McGuire, M.R., Behle, R.W., Shasha, B.S., GalánWong, L.J., 2000b. Assessment of microencapsulated formulations for improved residual activity of Bacillus thuringiensis. J. Econ. Entomol. 93, 219-225.

Tinoco, R., Halperin, D., 1998. Poverty, production and health: inhibition of erythrocyte cholinesterase through occupational exposure to organophosphate insecticides in Chiapas, Mexico. Arch. Environ. Health 53, 29-35.

Williams, T., Cisneros, J., 2001. Formulación y aplicación de los baculovirus bioinsecticidas. In: Caballero, P., López-Ferber, M., Williams, T. (Eds.), Los Baculovirus y sus Aplicaciones como Bioinsecticidas en el Control Biológico de Plagas, Phytoma, Valencia, Spain, pp. 313-372.

Williams, T., Goulson, D., Caballero, P., Cisneros, J., Martínez, A.M., Chapman, J.W., Roman, D.X., Cave, R.D., 1999. Evaluation of a baculovirus bioinsecticide for small scale maize growers in Latin America. Biol. Contr. 14, 67-75.

Winer, B.J., 1971. Statistical Principles in Experimental Design, second ed. McGraw-Hill, New York. 